\title{
Detection and molecular characterization of the Wolbachia Endobacteria in the Culex pipiens (Diptera: Culicidae) specimens collected from Kayseri province of Turkey
}

\author{
Alparslan YILDIRIM, Abdullah INCI, Onder DUZLU, Zuhal ONDER, Arif CILOGLU
}

Erciyes University Faculty of Veterinary Medicine, Department of Parasitology, Kayseri.

\begin{abstract}
Summary: This study was performed to investigate Wolbachia endobacteria in Culex pipiens specimens collected from Kayseri province of Turkey. For this aim, totally 10 genomic DNA pools each including 6-15 Cx. pipiens specimens which were collected and identified within the scope of a project (No: 107O533) supported by TUBITAK, were examined by using the amplification of surface protein gene (wsp) region of the Wolbachia. The sequences from this gene were highly variable and could be used to resolve the phylogenetic relationships of different Wolbachia strains. After the genomic DNA extraction from the pools, PCR analyses were carried out with Wolbachia specific primer pair which was amplified a 590-632 bp region of the wsp gene. Out of 6 of the 10 examined genomic DNA pools were found to be positive $(60.0 \%)$ by PCR analyses. The minimum infection rate of Wolbachia spp. in the totally analyzed 118 Cx. pipens specimens was determined as 5.08. One of the amplicon from the positive isolates was gel purified and sequenced in terms of wsp gene region of Wolbachia by using the same primers. Pair wise analyses of the obtained DNA sequences and multiple alignments with some other Wolbachia strains available in the GenBank were done and phylogenies were investigated. The obtained isolate (WolKys1) was deposited in GenBank International Nucleotide Sequence Database with the accession number JX474753. The phylogenetic analyses revealed that the obtained WolKys1 isolate belongs to Wolbachia Super Group B and wPIP group. According to the phylogenetic comparisons the WolKys1 showed 100.0\% identity with some other Wolbachia isolates under the Group B. In conclusion, this study reports the first molecular detection and characterization of Wolbachia endobacteria in Cx. pipiens populations in Turkey.
\end{abstract}

Key words: Cx. pipiens, molecular characterization, Turkey, Wolbachia.

\section{Kayseri yöresinden toplanmış Culex pipiens örneklerinde Wolbachia Endobakterisinin belirlenmesi ve moleküler karakterizasyonu}

Özet: Bu çalışma, Kayseri yöresinden toplanmış Culex pipiens örneklerinde Wolbachia endobakterisini araştırmak amacıyla yapılmıştır. Bu amaçla TÜBİTAK tarafından desteklenen 1070533 kod no'lu araştırma projesi kapsamında, Kayseri yöresinden toplanmış, $C x$. pipiens olarak identifiye edilmiş ve her birinde 6-15 adet C. pipiens türü içeren 10 adet genomik DNA havuzu materyal olarak belirlenmiştir. Genomik DNA havuzları Wolbachia yüzey protein (wsp) gen bölgesinin amplifikasyonu yönünden incelenmiştir. Bu gen bölgesinin sekansı yüksek değişkenlik göstermekte olup farklı Wolbachia suşları arasındaki filogenetik ilişkilerin analizinde kullanılabilmektedir. Havuzlardan genomik DNA ekstraksiyonunu takiben wsp gen bölgesinin 590-632 bp'lik kısmını amplifiye eden Wolbachia spesifik primerler ile PCR analizleri yapılmıştır. İncelenen 10 havuzun 6'sı (\%60,0) PCR analizleriyle pozitif bulunmuştur. İncelenen toplam 118 Cx. pipiens türünde Wolbachia spp. ile minimum enfeksiyon oran 5.08 olarak belirlenmiştir. Pozitif izolatlardan birine ait amplikon jel pürifiye edilmiş ve söz konusu gen bölgesi yönünden aynı primerler ile sekanslanmıştır. Elde edilen DNA dizisinin GenBank’ta mevcut diğer bazı Wolbachia suşları ile pairwise analizleri ve multiple alignmentları yapılarak filogenisi araştırılmıştır. Elde edilen izolat (WolKys1) JX474753 aksesyon numarası ile GenBank International Nucleotide Sequence Database'e kaydedilmiştir. Filogenetik analiz sonucu WolKys1 izolatının Wolbachia B süper grubu ve wPIP grubu içinde yer aldığı belirlenmiştir. Filogenetik kıyaslamalara göre WolKys1 izolatının B grubu altındaki diğer bazı Wolbachia izolatları ile \%100 identiklik gösterdiği saptanmıştır. Sonuç olarak bu çalışma ile Türkiye'de ilk kez Cx. pipiens populasyonlarında Wolbachia endobakterisinin moleküler olarak belirlenmesi ve karakterizasyonu yapılmıştır.

Anahtar sözcükler: $C x$. pipiens, moleküler karakterize, Türkiye, Wolbachia

\section{Introduction}

The intracellular bacteria Wolbachia are maternally inherited endosymbionts that a genus of the class Alphaproteobacteria and belonging to the order Rickettsiales. These gram-negative bacteria are found invertebrates including insects, arachnids, crustaceans and filarial nematodes (33). Infection prevalence is very high in insect orders; estimates suggest that $65 \%$ of insect species are infected with Wolbachia. These bacteria cause a number of reproductive alterations in 
their hosts, including cytoplasmic incompatibility (CI) in a wide range of insects $(5,8,24)$, parthenogenesis induction (PI) in a parasitoid wasps and thrips $(2,31,32)$, feminization of genetic males in isopods and moths, and killing of males in beetles, butterflies and a fruit fly (14, $15,20,21)$. Intracellular bacteria were first reported as Rickettsia-like microorganisms, within the ovaries and testes of the mosquito Culex pipiens by Hertig and Wolbach in 1924s. These bacteria were named as Wolbachia pipientis in 1936 (18). Based on the 16S rDNA gene and the protein-coding gene (groEL) sequence analysis, it has been confirmed into the family Anaplasmataceae which also includes of the genera Ehrlichia, Anaplasma, Cowdria, and Neorickettsia (24, 33). The gene phylogenies of the genus Wolbachia have shown the presence of eight major clades (A-H), have been named 'supergroups'. Supergroups A and B found in arthropods (36), supergroups C and D found in filarial nematodes (4), the E supergroup contain Wolbachia spp. from wingless insects, the springtails (Collembola) (35), members of supergroup $\mathrm{F}$ are known to infect arthropods (termites and scorpions) (3), and recent studies suggest that they also infect the filarial parasite Mansonella ozzardi, a causative agent of human filariasis $(9,22)$, members in supergroup $\mathrm{G}$ infect spiders and members in supergroup $\mathrm{H}$ are found termites and also more recently Dipetalonema gracile included under the Group H (28, 29).

The purpose of this study is to assess the presence of Wolbachia endobacteria in Cx. pipiens specimens using molecular tools and to estimate infection rates among Cx. pipiens populations collected from Kayseri province. Furthermore molecular characterization of a Wolbachia endobacteria isolate from $C x$. pipiens specimens based on wsp gene sequnces is also documented.

\section{Materials and Method}

Sampling area and Cx. pipiens specimens: The material of this study was obtained within the scope of a former research project supported by TUBITAK (No: 107O533) which investigates the prevalent mosquito species in Kayseri province and vector competence of the collected species for the nematode Dirofilaria immitis by molecular tools (42). Totally 10 genomic DNA pools each including 6-15 Cx. pipiens specimens were selected for the study.

DNA isolation: The pools were ground to a fine powder using liquid nitrogen in a pre-cooled mortar and pestle. DNA was extracted by using AxyPrep Multisource Genomic DNA Miniprep Kit (AP-MN-MSGDNA-250, Axygen Biosciences, USA) following the manufacturer's instructions. The final DNA pellet was dissolved in $50 \mu \mathrm{l}$ elution buffer and the extracted genomic DNA's were stored at $-20^{\circ} \mathrm{C}$ until PCR analysis.
DNA amplification: DNA concentrations of the extracted mosquito pools were measured by using Nano Drop Spectrophotometer (Bioneer ExiprepTM 16, Alameda, CA, USA) before PCR analyses in order to adjust optimum genomic DNA amounts used in the PCR analyses. Obtained genomic DNA's from pools were examined by using the wsp 81F (5'-TGG TCC AAT AAG TGA TGA AGA AAC) and wsp 691R (5'-AAA AAT TAA ACG CTA CTC CA) primers in order to amplification of a DNA fragment ranging from 590 to $632 \mathrm{bp}$ region of Wolbachia surface protein gene (wsp) (43). PCR was conducted with a total volume of $25 \mu 1$ consisting of $50 \mathrm{ng}$ of total genomic DNA, $2.5 \mu \mathrm{l}$ of $10 \mathrm{X}$ PCR buffer, $4 \mathrm{mM}$ of $\mathrm{MgCl} 2,0.4 \mu \mathrm{M}$ of each primer, 200 $\mathrm{mM}$ of each dNTP, 1U Taq DNA polymerase and deionized water. PCR amplifications were done under the following thermal profile: initial denaturation at $94{ }^{\circ} \mathrm{C}$ for $5 \mathrm{~min}$, followed by 35 cycles of amplification (denaturation at $94{ }^{\circ} \mathrm{C}$ for $1 \mathrm{~min}$, annealing at $55^{\circ} \mathrm{C}$ for 1 min, and extension at $72{ }^{\circ} \mathrm{C}$ for $1 \mathrm{~min}$ ) and a final extension at $72{ }^{\circ} \mathrm{C}$ for $10 \mathrm{~min}$. The amplification products were analyzed by electrophoresis in 1.5\% agarose gel, stained with ethidium bromide and visualized in CLP Gel Documentation System (UVP INC Uplant, CA).

DNA sequencing and analysis: One of the amplicon from the positive isolates was gel purified by a commercial kit (High Pure PCR product purification kit, Roche). The purified amplicon was sequenced in ABI PRISM 3100 genetic analyzer (Applied Biosystems, Foster City, CA, USA) in both directions by using 81F691R primers to obtain wsp gene sequences. The alignment of sequences was carried out using Clustal W method and phylogenetic analyzes of isolates were performed using the neighbor-joining (NJ) method with Geneious 5.5.5 software (13). The Kimura 2 Parameter model was utilized to estimate the evolutionary distances. Bootstrap re-sampling (1,000 cycles) was performed for each method to assess tree topology. Unique nucleotide sequence generated in the study was deposited in the GenBank International Nucleotide Sequence Database with the accession number JX474753 after checking carefully against the original chromatogram from the sequencing gel.

Calculation of the infection rates: Minimum infection rates (MIRs) with Wolbachia in the examined $C x$. pipiens specimens were calculated by the standard formula: (number of positive mosquito pools)/(total number of mosquitoes tested) X 100 (39).

\section{Results}

Presence of Wolbachia and minimum infection rates (MIRs) in Cx. pipiens specimens: Of the $10 C x$. pipiens genomic DNA pools screened, $6(60.0 \%)$ were found to be positive for Wolbachia with PCR analyses. 
Amplification of the DNA fragments ranging from 590 to 632 bp with the primers $81 \mathrm{~F}$ and $691 \mathrm{R}$ on the agarose gel are shown in Figure 1.

The minimum infection rate (MIRs) of Wolbachia spp. in the totally analyzed $118 C x$. pipens specimens was determined as 5.08 .
Sequence and phylogenetic analysis of Wolbachia surface protein gene: After the pairwise alignment of the two sequences obtained by using the two primers, the final sequence of the WolKys1 was generated. The nucleotide and amino acid sequences of the WolKys1 are presented in Figure 2.

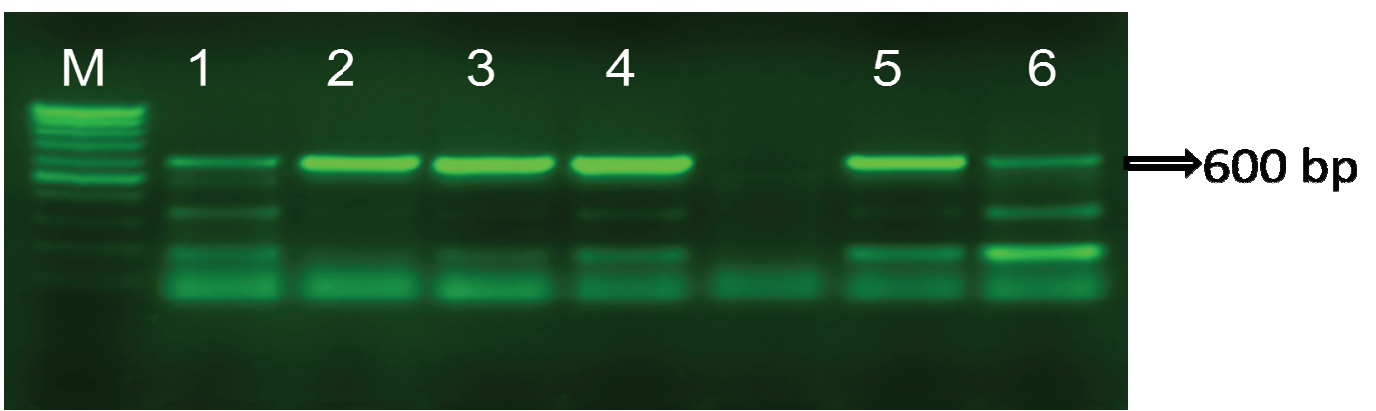

Figure 1. PCR results from Cx. pipiens genomic DNA pools with wsp general primers. M: 100 bp DNA ladder; 1-6: Wolbachia positives.

Şekil 1. Cx. pipiens genomic DNA havuzlarında wsp genel primerleri ile PCR sonuçları. M: 100 bp DNA ladder, 1-6: Wolbachia pozitifler.

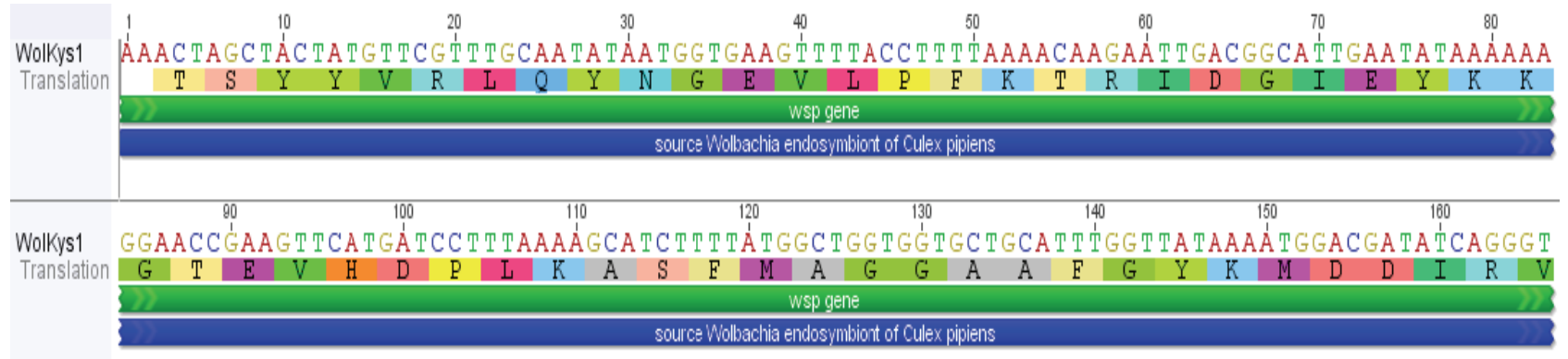

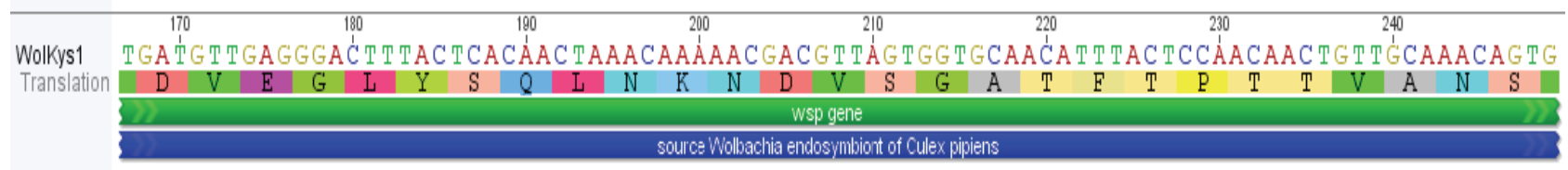

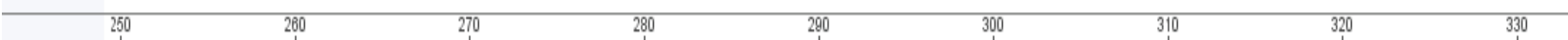

Wolkys1 TGGCAGCATTTCAGGATGGTAACGTTATTACATATÁCGATGAAGATAGCCTATCACTCCATACGTGGGTTGT

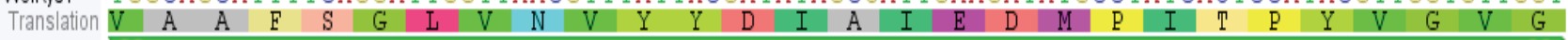

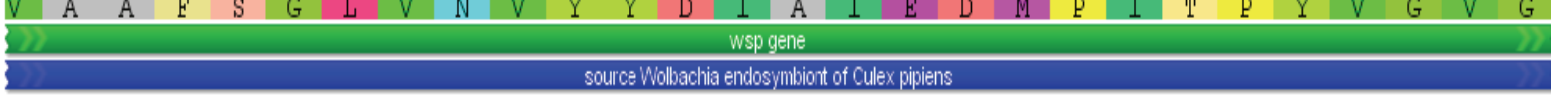

$\begin{array}{rrrrrrr}340 & 350 & 360 & 370 & 380 & 390 & 400\end{array}$

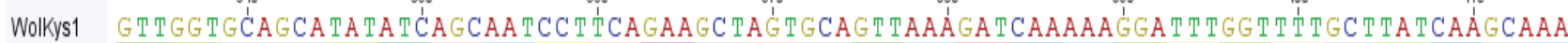

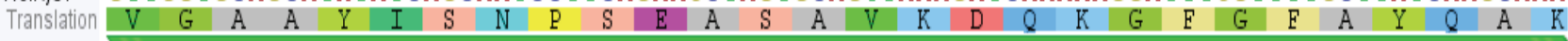

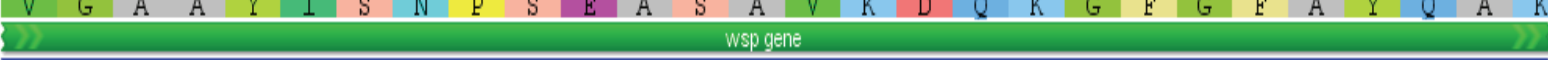
source Wolbachia endosymbiont of Culex pipiens

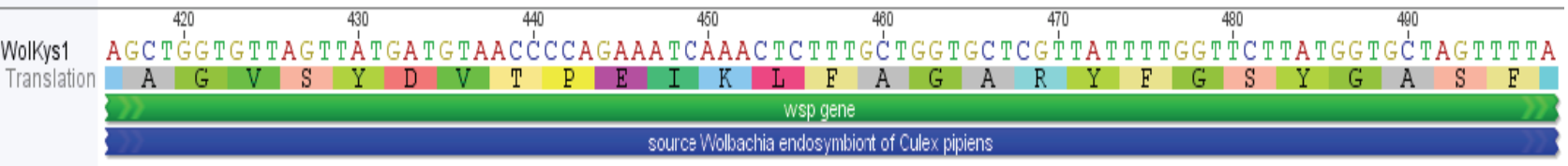

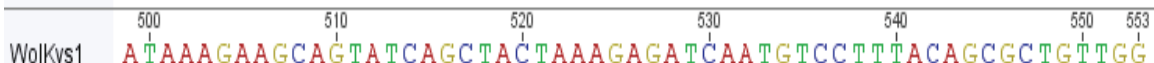

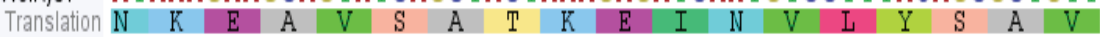

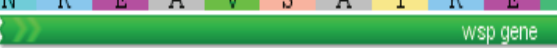

source Wolbachia endosymbiont of Culex pipiens

Figure 2. Nucleotide and amino acid sequences of WolKys1 isolate detected from Cx. pipiens specimens.

Şekil 2. Cx. pipiens örneklerinde saptanan WolKys1 izolatının nükleotid ve amino asit dizilimleri. 


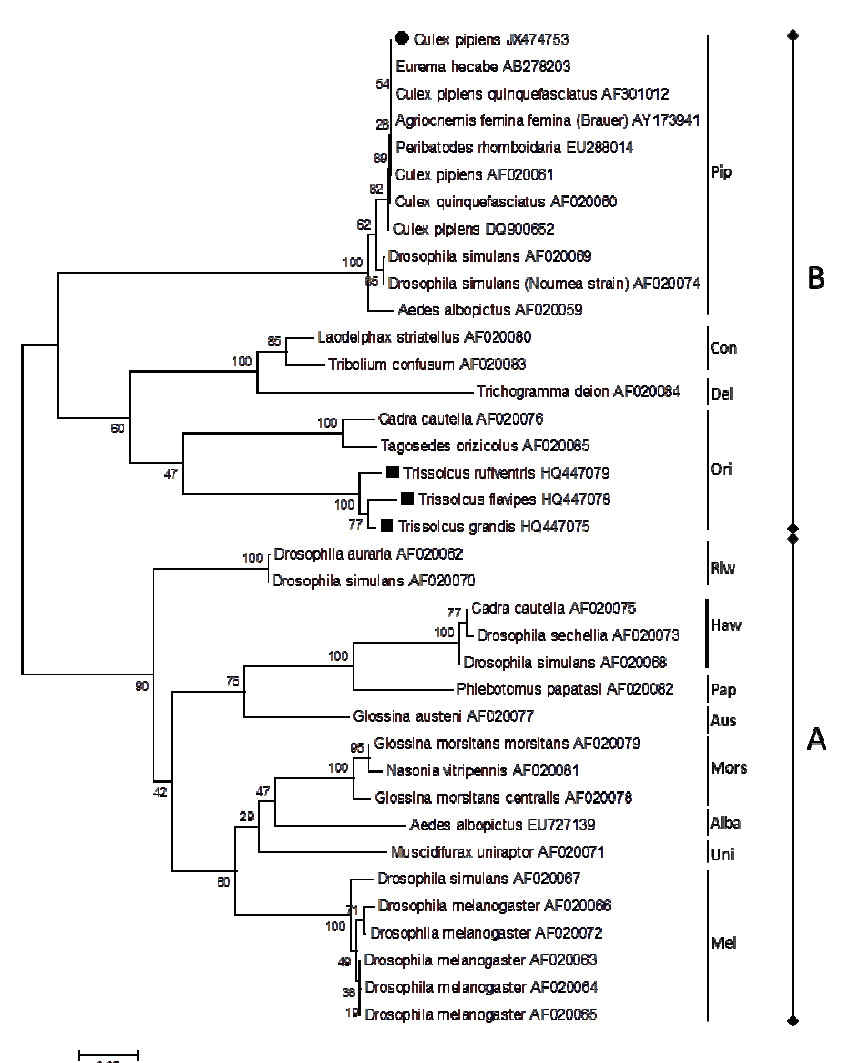

Figure 3. Phylogenetic relationship among WolKys1 and some other Wolbachia isolates (Neighbour Joining-Kimura 2 Parameter model) from different groups available in GenBank. - : WolKys1 isolate from Kayseri province. a: Wolbachia isolates from Trissolcus sp. in Turkey. Scale bar indicates number of nucleotide substitutions per site.

Şekil 3. WolKys1 izolatı ile GenBankta mevcut farklı gruplardan diğer bazı Wolbachia izolatları arasındaki filogenetik ilişki (Neighbour Joining - Kimura 2 Parameter model). • : Kayseri yöresinden WolKys1 izolatı. — : Türkiye'de Trissolcus türlerinde Wolbachia izolatı. Ölçek çizgisi bölgeye göre nükleotid değişim sayısını göstermektedir.

A phylogenetic tree was constructed after the multiple alignment of the WolKys1 with some other Wolbachia strains in different taxa in the GenBank by using Neighbor Joining method (Kimura 2 parameter model, Bootstrap re-sampling 1000 cycles) (Fig 3). The phylogenetic analyses revealed that the WolKys1 isolate obtained from $C x$. pipens specimens belongs to Wolbachia Super Group B and wPIP group.

According to the phylogenetic comparisons the WolKys 1 showed $100.0 \%$ identity with the isolates obtained from Cx. pipiens (DQ900652, AF301012, AF020060-61), Peribadotes rhomboidaria (EU288014), Agriocnemis femina femina (Brauer) (AY173941) and Eurema hecabe (AB278203) under the Pip group. Mean genetic diversity in Pip group was determined as $0.5 \pm 0.1 \%$ whereas $22.8 \pm 2.0 \%, 19.5 \pm 2.0 \%$ and $26.0 \pm 2.5 \%$ mean difference were found between Pip and Ori, Con, Dei groups, respectively. The mean phylogenetic difference between Pip group and other isolates under the Super group A was calculated as $25.0 \pm 2.0 \%$.

\section{Discussion and Conclusion}

Wolbachia is the most common intracellular endobacterium that present in more than $65 \%$ of insect species and found in all major insect orders including Coleoptera, Diptera, Hemiptera/Homoptera, Hymenoptera, Lepidoptera, and Orthoptera $(11,19,27,38)$. Some medically important mosquito specimens are reported to be naturally and/or artificially infected with Wolbachia, such as the common house mosquito $C x$. pipiens (1, 26, 41), the Asian tiger mosquito Aedes albopictus (24) and the yellow fever mosquito Ae. aegypti $(23,30,40)$. The number of infected insect species with Wolbachia has been increasing rapidly in recent years. Recent progress in molecular techniques particularly has allowed to systematic surveys of Wolbachia distribution and diversity more reliable. The $16 \mathrm{~S}$ rRNA, fts $Z$ and $w s p$ gene region studies have provided a number of useful molecular tools for such genotyping Wolbachia strains from different hosts $(27,37)$. Among these gene regions outer membrane protein of Wolbachia (wsp) was determined to be highly variable and sequences from this gene region provides much more informative features for determining the evolutionary relationships among Wolbachia strains $(16,43)$. It was also reported that phylogenetic diversity in the wsp gene is almost 10 times greater than the divergence described in 16S rRNA gen region $(24,43)$. Wsp gen region was also chosen in this study for investigating and genotyping of Wolbachia in $C x$. pipiens specimens due to its advantages and usefulness in the phylogenetic analyses. In this study $60.0 \%$ of the examined $C x$. pipiens pools were found to be positive for Wolbachia with PCR analyses of wsp gene region and the minimum infection rate (MIRs) of Wolbachia spp. in the totally analyzed Cx. pipens specimens was determined as 5.08. Behbahani (6) also determined Culex pipiens quinquefasciatus specimens collected from Shoushtar in south west of Iran were infected with Wolbachia, while no infection was found in $C x$. tritaeniorynchus and Cx. theileri specimens in the study (6). In South India, Sunish et al (34) also reported high Wolbachia prevalence in totally 750 adult $C x$. pipiens quinquefasciatus by PCR. Duron et al (12) reported Wolbachia infection in 178 field-caught $C x$. pipiens specimens from four locations (Ganges, Saint Bauzille de Putois, Maurin and Viols le Fort) in France. Ravikumar et al (28) determined Wolbachia infection as $20 \%$ and $50 \%$ in Aedes and Culex populations by PCR using Wolbachia specific wsp gene primers in India. Rasgon and Scott (27) tested 14 North American mosquito species in five genera (Aedes, Anopheles, Culiseta, Culex and Ochlerotatus) for Wolbachia infection, but the infections were reported only in $C x$. pipiens species complex. The presence and prevalence of Wolbachia in Cx. pipiens populations in our study are in agreement with the related studies $(6,12,27,34)$. 
In arthropods several gene regions such as $16 \mathrm{~S}$ rDNA and ftsZ, have been used for molecular characterization and phylogenetic analysis of Wolbachia strains $(4,7,10,22,24)$. However, molecular genotyping by using these gen regions has only been able to resolve a limited number of broad Wolbachia strain groupings, determined as $\mathrm{A}$ and $\mathrm{B}$ and two groups within the $\mathrm{A}$ group based on ftsZ sequences $(36,43)$. However, applying wsp gene sequence analysis in the phylogenetic relationships among Wolbachia strains revealed some distinct clades within both the groups A and B (43). A total of 8 and 4 genetically different potential groups (Fig. 3) were determined in A and B super groups, respectively (43). In this study the Wolbachia isolate obtained from $C x$. pipiens specimens was characterized in Wolbachia Supergroup B and wPip group. This result is consistent with some other studies which also reported Wolbachia strains from $C x$. pipiens in different regions belong to wPip group of B super group $(1,12,25,43)$ and also the obtained WolKys 1 isolate was found to be $100.0 \%$ identical with some other isolates under the wPip group. It was also reported that there was high genetic divergence among the groups within each super group and the diversity was much greater in super group B than super group A (43). Similarly, mean genetic diversity was found higher $(19.5 \%-26.0 \%)$ when comparing the Pip group with the Ori, Con, Dei groups under Super group B where as high identity rate (99.5\%) was determined among isolates under the Pip group. The mean phylogenetic difference between Pip group and other isolates under the Super group A was also found higher $(25.0 \%)$. In addition a high genetic diversity $(23.1 \%)$ was also determined among the WolKys1 isolate and Wolbachia isolates reported from Trissolcus rufiventris, T. flavipes and T. grandis in Turkey which are known to be specific enemies of stink bugs (17).

In conclusion, this study describes the first molecular detection and characterization of Wolbachia endobacteria in $C x$. pipiens specimens captured in Kayseri province of Turkey based on wsp gene analyses. The knowledge about the Wolbachia infections in several kinds of arthropods found in Turkey is still inadequate. Therefore further studies should be conducted to determine the distribution and genotyping of Wolbachia endobacteria found in arthropods.

\section{Acknowledgements}

The authors are grateful to TUBITAK for supporting the study material with project number $107 \mathrm{O}$ 533. This article was presented at $1^{\text {st }}$ National Symposium on Vectors and Vector-Borne with International Participation, 9-10 September, 2012, Avanos, Cappadocia, Nevsehir, Turkey.

Conflict of interest statement: None of the authors of this paper has a financial or personel relationsship with other people or organizations that could inappropriately influence or bias the content of the paper.

\section{References}

1. Almeida F, Moura AS, Cardoso AF, Winter CE, Tania Bijovsky A, Suesdek L (2011): Effects of Wolbachia on fitness of Culex quinquefasciatus (Diptera; Culicidae). Infect Genet Evol, 11, 2138-2143.

2. Arakaki N, Miyoshi T, Noda H (2001): Wolbachiamediated parthenogenesis in the predatory thrips Franklinothripsvespiformis (Thysanoptera: Insecta). Proc R Soc Lond B Biol Sci, 268, 1011-1016.

3. Baldo L, Prendini L, Corthals A, Werren JH (2007): Wolbachia are present in southern African scorpions and cluster with supergroup F. Curr Microbiol, 55, 367-373.

4. Bandi C, Anderson TJ, Genchi C, Blaxter ML (1998): Phylogeny of Wolbachia in filarial nematodes. Proc R Soc, 265, 2407-2413.

5. Barr AR (1980): Cytoplasmic incompatibility in natural populations of a mosquito, Culex pipiens L. Nature, 283, 71-72.

6. Behbahani A (2012): Wolbachia infection and mitochondrial DNA comparisons among Culex mosquitoes in South West Iran. Pak J Biol Sci, 15, 54-57.

7. Bordenstein S, Rosengaus RB (2005): Discovery of a novel Wolbachia super group in Isoptera. Curr Microbiol, 51, 393-398.

8. Breeuwer JAJ, Stouthamer R, Burns DA, Pelletier DA, Weisburg WG, Werren JH (1992): Phylogeny of cytoplasmic cytoplasmic incompatibility microorganisms in the parasitoid wasp genus Nasonia (Hymenoptera: Pteromalidae) based on 16 s ribosomal DNA sequences. Insect Mol Biol, 1, 25-36.

9. Casiraghi M, Favia G, Cancrini G, Bartoloni A, Bandi C (2001): Molecular identification of Wolbachia from the filarial Nematode Mansonella ozzardi. Parasitol Res, 87, 417-420.

10. Casiraghi M, Bordenstein SR, Baldo L, Lo N, Beninati T, Wernegreen JJ, Werren JH, Bandi C (2005): Phylogeny of Wolbachia pipientis based on gltA, groEL and ftsZ gene sequences: clustering of arthropod and nematode symbionts in the F supergroup, and evidence for further diversity in the Wolbachia tree. Microbiol, 151, 4015-4022.

11. Duron O, Bouchon D, Boutin S, Bellamy L, Zhou L, Engelstädter J, Hurst GD (2008): The diversity of reproductive parasites among arthropods: Wolbachia do not walk alone. BMC Biol, 6, 27.

12. Duron O, Raymond M, Weill M (2011): Many compatible Wolbachia strains coexist within natural populations of Culex pipiens mosquito. Heredity, 106, 986993.

13. Drummond AJ, Ashton B, Buxton S, Cheung M, Cooper A, Duran C, Field M, Heled J, Kearse M, Markowitz S, Moir R, Stones-Havas S, Sturrock S, Thierer T, Wilson A (2011): Geneious v5.5, Available from http://www.geneious.com. (18.10.2011).

14. Fialho RF, Stevens L (1997): Molecular evidence for single Wolbachia infections among geographic strains of the flour beetle Tribolium confusum. Proc R Soc Lond B Biol Sci, 264, 1065-1068. 
15. Fialho RF, Stevens L (2000): Male-killing Wolbachia in a flour beetle. Proc R Soc Lond B Biol Sci, 267, 1469-1474.

16. Goward CR, Scawen MD, Murphy JP, Atkinson T (1993): Molecular evolution of bacterial cell-surface proteins. Trends Biochem Sci, 18, 136-140.

17. Guz N, Kocak E, Akpınar E, Gurkan O, Kılıncer N (2012): Wolbachia infection in Trissolcus species (Hymenoptera: Scelionidae). Eur J Entomol, 109, 169-174.

18. Hertig M (1936): The rickettsia Wolbachia pipientis (gen. et. sp. n) and associated inclusions of the mosquito, Culex pipiens. Parasitol, 28, 453-486.

19. Hilgenboecker K, Hammerstein P, Schlattmann P, Telschow A, Werren JH (2008): How many species are infected with Wolbachia? A statistical analysis of current data. FEMS Microbiol Lett, 281, 215-220.

20. Hurst GDD, Jiggins FM, von der Schulenburg JHG, Bertrand D, West SA, Goriacheva II, Zakhrov IA, Werren JH, Stouthamer R, Majerus MEN (1999): Male-killingWolbachia in two species of insect. Proc R Soc Lond B Biol Sci, 266, 735-740.

21. Hurst GDD, Johnson AP, von der Schulenburg JHG, Fuyama Y (2000): Male-killing Wolbachia. Drosophila: a temperature sensitive trait with a threshold bacteria density. Genetics, 156, 699-709.

22. Lo N, Casiraghi M, Salati E, Bazzocchi C, Bandi C (2002): How many Wolbachia supergroups exist? Mol Biol Evol, 19, 341-346.

23. McMeniman CJ, Lane RV, Cass BN, Fong AW, Sidhu M, Wang YF, O'Neill SL (2009): Stable introduction of a life-shortening Wolbachia infection into the mosquito Aedes aegypti. Science, 323, 141-144.

24. O'Neill SL, Giordano R, Colbert AM, Karr TL, Robertson HM (1992): 16srRNA phylogenetic analysis of the bacterial endosymbionts associated with cytoplasmic incompatibility in insects. Proc Natl Acad Sci USA, 89, 2699-2702.

25. Pidiyar VJ, Jangid K, Patole MS, Shouche YS (2003): Detection and phylogenetic affiliation of Wolbachia sp. from Indian mosquitoes Culex quinquefasciatus and Aedes albopictus. Curr Sci, 84, 1136-1139.

26. Rasgon JL, Scott TW (2003): Wolbachia and cytoplasmic incompatibility in the California Culex pipiens mosquito species complex: parameter estimates and infection dynamics in natural populations. Genetics, 165, 20292038.

27. Rasgon JL, Scott TW (2004): An initial survey for Wolbachia (Rickettsiales: Rickettsiaceae) infections in selected California mosquitoes (Diptera: Culicidae). J Med Entomol, 41, 255-257.

28. Ravikumar H, Ramachandraswamy N, Sampathkumar S, Prakash BM, Huchesh HC, Uday J, Puttaraju HP (2010): A preliminary survey for Wolbachia and bacteriophage WO infections in Indian mosquitoes (Diptera: Culicidae). Trop Biomed, 27, 384-393.

29. Rowley SM, Raven RJ, McGraw EA (2004): Wolbachia pipientis in Australian spiders. Curr Microbiol, 49, 208214.
30. Ruang-Areerate T, Kittayapong P (2006): Wolbachia trans infection in Aedes aegypti: A potential gene driver of dengue vectors. Proc Natl Acad Sci USA, 103, 1253412539.

31. Stouthamer R, Luck RF, Hamilton WD (1990): Antibiotics cause parthenogenetic Trichogramma to revert to sex. Proc Natl Acad Sci USA, 87, 2424-2427.

32. Stouthamer R, Breeuwer JAJ, Luck RF, Werren JH (1993): Molecular identification of microorganisms associated with parthenogenesis. Nature, 361, 66-68.

33. Sungpradit S, Nuchprayoon S (2010): Wolbachia of arthropods and filarial nematodes: biology and applications. Chula Med J, 54, 605-621.

34. Sunish IP, Rajendran R, Paramasivan R, Dhananjeyan KJ, Tyagi BK (2011): Wolbachia endobacteria in a natural population of Culex quinquefasciatus from filariasis endemic villages of South India and its phylogenetic implication. Trop Biomed, 28, 569-576.

35. Vandekerckhove TT, Watteyne S, Willems A, Swings JG, Mertens J, Gillis M (1999): Phylogenetic analysis of the $16 \mathrm{~S}$ rDNA of the cytoplasmic bacterium Wolbachia from then ovel host Folsomia candida (Hexapoda, Collembola) and its implications for Wolbachial taxonomy. FEMS Microbiol Lett, 180, 279-286.

36. Werren JH (1997): Biology of Wolbachia. Annu Rev Entomol, 42, 587-609.

37. Werren JH, Windsor DM (2000): Wolbachia infection frequencies in insects:evidence of a global equilibrium? Proc R Soc Lond B, 267, 1277-1285.

38. Werren JH, Zhang W, Guo LR. (1995): Evolution and phylogeny of Wolbachia: reproductive parasites of arthropods. Proc R Soc Lond B, 261, 55-63.

39. White BJ, Andrew DR, Mans NZ, Ohajuruka OA, Garvin MC (2006): West Nile virus in mosquitoes of northern Ohio, 2003. Am J Trop Med Hyg, 75, 346-349.

40. Xi Z, Khoo CC, Dobson SL (2005): Wolbachia establishment and invasion in an Aedes aegypti laboratory population. Science, 310, 326-328.

41. Yen JH, Barr AR (1971): New hypothesis of the cause of cytoplasmic incompatibility in Culex pipiens L. Nature, 232, 657-658.

42. Yildirim A, Inci A, Duzlu O, Biskin Z, Ica A, Sahin I (2011): Aedes vexans and Culex pipiens as the potential vectors of Dirofilaria immitis in Central Turkey. Vet Parasitol 178,143-147.

43. Zhou W, Rousset F, O'Neill SL (1998): Phylogeny and PCR-based classification of Wolbachia strains using wsp gene sequences. Proc R Soc Lond Ser B, 265, 509-515.

Geliş tarihi: 14.02.2013 / Kabul tarihi: 27.03.2013

Address for correspondence:

Doç. Dr. Alparslan Yıldırım

Department of Parasitology,

Faculty of Veterinary Medicine,

Erciyes University,

38090 Melikgazi, Kayseri, Turkey

e-mail:yildirima@erciyes.edu.tr 